\title{
Detection of selected pathogens in ticks collected from cats and dogs in the Wrocław Agglomeration, South-West Poland
}

Nina Król ${ }^{*}$, Anna Obiegala², Martin Pfeffer ${ }^{2}$, Elżbieta Lonc ${ }^{1}$ and Dorota Kiewra ${ }^{1}$

\begin{abstract}
Background: Tick-borne infections are no longer confined to rural areas, they are documented with increasing frequency in urban settlements across the world. They are known to cause diseases in humans as well as in their companion animals.

Methods: During a period of 2 years, from January 2013 until December 2014, ticks were collected from dogs and cats in 18 veterinary clinics in the Wrocław Agglomeration, Poland. In total, 1455 ticks were found on 931 pets: 760 domestic dogs and 171 cats. For molecular examinations 127 I. ricinus ticks (115 females and 12 males) were randomly selected, all collected I. hexagonus ( $n=137,32$ females, 98 nymphs, 7 larvae) and all collected D. reticulatus ( $n=46,31$ females, 15 males) were taken. Ixodes ricinus and I. hexagonus ticks were tested for Rickettsia spp., Anaplasma phagocytophilum, Candidatus Neoehrlichia mikurensis and Babesia spp., while D. reticulatus ticks were investigated for Rickettsia spp. and Babesia spp. only.

Results: In total, $65.4 \%$ I. ricinus ticks were infected with at least one pathogen. Over $50 \%$ of I. ricinus were positive for Rickettsia spp. (R. helvetica and R. monacensis). The infection level with A. phagocytophilum was $21.3 \%$. DNA of Cand. N. mikurensis was detected in $8.1 \%$ I. ricinus ticks. Interestingly only female ticks were infected. The prevalence of Babesia spp. was confirmed in $9.0 \%$ of I. ricinus involving the species B. microti and B. venatorum. A total of nineteen double, one triple and two quadruple infections were found in I. ricinus ticks only. Almost $11 \%$ of I. hexagonus ticks were positive for at least one of the tested pathogens. Rickettsia spp. infection was found in $2.2 \%$, while A. phagocytophilum was detected in $8.1 \%$ of I. hexagonus ticks. Only one nymph was positive for Cand. N. mikurensis and none of I. hexagonus ticks harbored a Babesia spp. Over $60 \%$ of D. reticulatus ticks were positive for rickettsial DNA, exclusively belonging to the species $R$. raoultii.
\end{abstract}

Conclusion: The high tick infestation rates and the prevalence of pathogens found in these ticks demonstrate a serious level of encounter to tick-borne diseases in urban dogs in the Wroclaw area, and provide evidence that dogs and cats themselves may substantially contribute to the circulation of the ticks and pathogens in the urban area.

Keywords: Rickettsia spp., Anaplasma phagocytophilum, Candidatus Neoehrlichia mikurensis, Babesia spp., Ixodes ricinus, Ixodes hexagonus, Dermacentor reticulatus, Ticks, Dogs, Cats

\footnotetext{
*Correspondence: nina.krol2@uwr.edu.pl

${ }^{1}$ Department of Microbial Ecology and Environmental Protection, Institute of

Genetics and Microbiology, University of Wrocław, Przybyszewskiego 63/77,

51-148 Wrocław, Poland

Full list of author information is available at the end of the article
} 


\section{Background}

Tick-borne pathogens, such as Anaplasma phagocytophilum, Candidatus Neoehrlichia mikurensis and Rickettsia spp., belong to the order Rickettsiales, while such as Babesia spp. are parasitic protozoans. All these pathogens, are known to cause diseases in humans as well as in their companion animals, and are considered to be emerging across Europe and other parts of the world [1-6].

Rickettsia spp. are divided into four groups: the spotted fever group (SFG), the typhus group, the Rickettsia bellii group, and the Rickettsia canadensis group [7]. Rickettsiae of the SFG are known to be transmitted by ticks and cause DEBONEL (Dermacentor-borne necrosis erythema lymphadenopathy), also known as TIBOLA (tick-borne lymphadenopathy) in humans [8]. In Poland, rickettsioses caused by rickettsiae of the SFG were described in forest workers, dogs and ticks [9-11].

Anaplasma phagocytophilum and Candidatus Neoehrlichia mikurensis are gram-negative obligate intracellular bacteria. Anaplasma phagocytophilum may cause granulocytic anaplasmosis in humans, dogs, horses and ruminants [4]. Anaplasmosis has been reported in dogs, cats and humans from Poland with evidence of autochthonous human cases [12-15]. Neoehrlichiosis was described in immunodeficient and previously healthy humans but also in immunodeficient dogs $[1,3,16]$. The presence of Cand. Neoehrlichia mikurensis has been proven in Ixodes ricinus ticks and in asymptomatic humans from Poland [17, 18].

Babesiosis is a zoonotic disease occurring worldwide which is caused by intraerythrocytic parasites of the genus Babesia [2]. In Europe, Babesia divergens-like organisms are mainly responsible for the disease in humans. Babesia spp. are reported in Ixodes ricinus and Dermacentor reticulatus from Poland [19]. Nowadays, cases caused by tickborne pathogens are emerging in urban regions in Europe $[20,21]$. Dogs and cats should be taken into account as important hosts of ticks in urban areas [21, 22].

In Poland, 5 of the 19 detected tick species (I. ricinus Linnaeus, 1758, I. hexagonus Leach, 1815, I. crenulatus Koch, 1844, I. rugicollis Schulze et Schlottke, 1929, and D. reticulatus Fabricius, 1794) parasitize on cats and dogs [23]. Most commonly, however, I. ricinus and D. reticulatus, the important vectors of Rickettsia spp., Anaplasma phagocytophilum and Babesia spp., are detected on pets [21, 24-28]. In a previous study, ticks collected from cats and dogs from the Wrocław Agglomeration, SW Poland, were tested for the presence of Borrelia spp. [29].

The aim of this follow-up study was to evaluate the prevalence of Babesia spp., A. phagocytophilum, Cand. Neoehrlichia mikurensis and Rickettsia spp. in ticks collected from cats and dogs in the Wrocław Agglomeration, Poland.

\section{Methods}

\section{Tick collection}

During a period of 2 years, from January 2013 till December 2014, ticks were collected from dogs and cats in the veterinary clinics in the Wrocław Agglomeration, Poland. Wrocław city $\left(c 292.8 \mathrm{~km}^{2}\right)$ is located in the south-west of Poland $\left(51^{\circ} 07^{\prime} \mathrm{N}, 17^{\circ} 02^{\prime} \mathrm{E}\right)$. Tick collection from 2013 [29] was extended with specimens collected in the next year. In total, 18 veterinary clinics submitted 1455 ticks found on 931 pets: 760 domestic dogs and 171 cats (Table 1). Tick specimens were determined by life stage, sex and species [30]. Tick collection consisted of: 46 D. reticulatus ticks (31 females, 15 males), 137 I. hexagonus (32 females, 98 nymphs, 7 larvae), and 1272 I. ricinus (1160 females, 103 males, 9 nymphs).

\section{DNA isolation and biological material}

All collected ticks were kept in $70 \%$ ethanol until isolation of DNA was performed. Before DNA extraction, ticks were washed in sterile water. All ticks were individually homogenized using sterile polystyrene pistils and then genomic DNA was extracted by using a Tissue Genomic Extraction GPB Mini Kit with proteinase $\mathrm{K}$ (Genoplast Biochemicals, Poland) according to the manufacturer's instructions. All of the obtained lysates were stored at $-20{ }^{\circ} \mathrm{C}$ until examined.

For further examinations 310 ticks were selected: 127 randomly chosen $I$. ricinus ticks (115 females and 12 males), all collected $I$. hexagonus ticks ( $n=137 ; 32$ females, 98 nymphs, 7 larvae) and $D$. reticulatus ticks ( $n=$ 46; 31 females, 15 males) (Table 2). Ixodes ricinus and $I$. hexagonus ticks were tested for Rickettsia spp., Anaplasma phagocytophilum, Candidatus Neoehrlichia mikurensis and Babesia spp., while D. reticulatus ticks were only investigated for Rickettsia spp. and Babesia spp.

Molecular detection of Rickettsia spp., Anaplasma phagocytophilum, Candidatus Neoehrlichia mikurensis and Babesia spp.

For detection of Rickettsia spp., a real-time PCR targeting the gltA genome region (70 bp) was used [31]. A real-time PCR targeting $m s p 2$ gene fragment (77 bp) was performed to detect $A$. phagocytophilum [32]. In order

Table 1 Ticks collected from pets in the Wrocław Agglomeration (Poland), 2013-2014

\begin{tabular}{llll}
\hline Species & \multicolumn{3}{l}{ Number of ticks / number of hosts } \\
\cline { 2 - 4 } & Cats & Dogs & Total \\
\hline Dermacentor reticulatus & $2 / 2$ & $44 / 34$ & $46 / 36$ \\
Ixodes hexagonus & $53 / 7$ & $84 / 37$ & $137 / 44$ \\
Ixodes ricinus & $267 / 162$ & $1005 / 689$ & $1272 / 851$ \\
Total & $322 / 171$ & $1133 / 760$ & $1455 / 931$ \\
\hline
\end{tabular}


Table 2 Ticks investigated for pathogens, the Wrocław Agglomeration (Poland), 2013-2014

\begin{tabular}{|c|c|c|c|c|c|c|c|c|c|c|c|c|c|}
\hline \multirow[t]{4}{*}{ Pathogens } & \multicolumn{13}{|c|}{ Number of tick stages } \\
\hline & \multicolumn{3}{|c|}{ Females } & \multicolumn{3}{|l|}{ Males } & \multicolumn{3}{|c|}{ Nymphs } & \multicolumn{3}{|c|}{ Larvae } & \multirow[t]{3}{*}{ Tota } \\
\hline & \multicolumn{12}{|c|}{ Collected from } & \\
\hline & Total & Cats & Dogs & Total & Cats & Dogs & Total & Cats & Dogs & Total & Cats & Dogs & \\
\hline D. reticulatus & 31 & 2 & 29 & 15 & - & 15 & - & - & - & - & - & - & 46 \\
\hline I. hexagonus & 32 & 5 & 27 & - & - & - & 98 & 43 & 55 & 7 & 5 & 2 & 137 \\
\hline I. ricinus & 115 & 34 & 81 & 12 & 4 & 8 & - & - & - & - & - & - & 127 \\
\hline Total & 178 & 41 & 137 & 27 & 4 & 23 & 98 & 43 & 55 & 7 & 5 & 2 & 310 \\
\hline
\end{tabular}

to detect Candidatus Neoehrlichia mikurensis, a realtime PCR targeting the partial groEL gene (99 bp) was used [33, 34]. All PCR methods were carried out using the Mx3000P real-time cycler (Stratagene).

For detection of Babesia spp., a conventional PCR amplification of the small $18 \mathrm{~S}$ subunit of the rRNA gene (411-452 bp) with primers BJ1 and BN2 was performed [35]. Samples positive for Rickettsia spp. DNA by realtime PCR were further investigated using a conventional PCR in which a 811-bp fragment of the $\operatorname{smp} B$ gene was amplified [36]. The PCR products were visualized by electrophoresis on $1.5 \%$ agarose gels stained with Midori Green (NIPPON Genetics, Düren, Germany). Randomly selected positive PCR products $(n=22)$ were purified using the NucleoSpin ${ }^{\odot}$ and PCR Clean-up Kit (MACHEREY-NAGEL, Düren, Germany) according to the manufacturer's instructions. Purified PCR products were sequenced (Interdisziplinäres Zentrum für Klinische Forschung, Leipzig, Germany) with forward and reverse primers, and analyzed with Chromas Lite (Technelysium Pty Ltd, Australia). Nucleotide sequences were compared with GenBank entries using NCBI BLAST.

\section{Statistical analysis}

The chi-square test was used to compare infected and not infected ticks (STATISTICA ver. 9.0). Yates' correction was used for 1- $d f$ tests when expected frequencies were less than 5 . The significance level was set at 0.05 .

\section{Results}

The most common infection was Rickettsia spp., which was found in $30.6 \%(n=95)$ of all tick species (Table 3$)$. The highest infection level was detected in $D$. reticulatus ticks $(60.9 \%)$, followed by I. ricinus $(50.4 \%)$ and $I$. hexagonus $(2.2 \%)$. The differences in prevalence between tick species were statistically significant $\left(\chi^{2}=95.268, d f=2\right.$, $P<0.001)$. Rickettsia raoultii was found in $100 \%$ sequenced $D$. reticulatus samples (100\% identity to acc. no. JX298077.1). In $I$. ricinus ticks, the distribution of Rickettsia spp. was $80 \%$ for $R$. helvetica (100\% identity to acc. no. KR150781.1) and $20 \%$ for $R$. monacensis (100 \% identity to KC137254.1). DNA from I. hexagonus was not tested due to high $\mathrm{CT}$ values previously obtained by RT-PCR $(\mathrm{CT}>35)$. The prevalence of $A$. phagocytophilum was detected in $14.4 \%(n=37)$ of Ixodes species. Further, $21.3 \%$ of $I$. ricinus, and $8.1 \%$ of I. hexagonus were positive for this pathogen. The infection level was statistically higher in I. ricinus ticks than $I$. hexagonus $\left(\chi^{2}=9.01, d f=1, P=0.003\right)$. Candidatus $\mathrm{N}$. mikurensis was found in $4.2 \%$ of Ixodes samples. It was detected in $8.1 \%$ of $I$. ricinus and $0.7 \%$ of $I$. hexagonus (the difference being statistically significant, $X^{2}=8.599$, $d f=1, P=0.003)$. The prevalence of Babesia spp. was the lowest among the tested pathogens, $3.6 \%(n=11)$ for all tick species, but only $I$. ricinus ticks (9.0\%) were infected $\left(\chi^{2}=16.934, d f=2, P<0.001\right)$. Babesia microti was detected in $83.3 \%$ (all samples with identity over $96 \%$ to acc. no. JQ711225.1), and B. venatorum in $16.7 \%$ (identical with $99 \%$ to acc. no. KR493907.1 and $98 \%$ to KF500410.1) of sequenced I. ricinus samples.

Ixodes ricinus ticks were more often infected, with minimum one pathogen, than $I$. hexagonus or $D$. reticulatus $\left(\chi^{2}=90.019, d f=2, P<0.001\right)$. In total, $65.4 \%(n=$ 83) I. ricinus ticks were positive for at least a single infection. The most often detected pathogen was Rickettsia spp. $\left(\chi^{2}=84.505, d f=3, P<0.0001\right)$, in $50.4 \%$ of $I$. ricinus $(n=64$; Table 3$)$. There were no significant differences in infection levels between females and males $\left(\chi^{2}\right.$ $=0.404, d f=1, P=0.525)$ nor ticks collected from cats or dogs $\left(\chi^{2}=0.694, d f=1, P=0.405\right)$. Anaplasma phagocytophilum was verified in $21.3 \%$ specimens $(n=26$, no statistically significant differences were observed between females and males, $\chi^{2}=0.259, d f=1, P=0.611$, or between ticks parasitizing cats or dogs, $\chi^{2}=0.002, d f=1$, $P=0.964)$. Candidatus N. mikurensis was detected in $8.1 \%$ I. ricinus $(n=10)$, only females were infected $\left(\chi^{2}=\right.$ $0.202, d f=1, P=0.653)$; infection level of ticks collected from pets was not statistically significant $\left(\chi^{2}=0.097, d f\right.$ $=1, P=0.755)$. The prevalence of Babesia spp. was confirmed in $9.0 \%$ of specimens $(n=11)$; there were neither significant differences between females and males $\left(\chi^{2}=\right.$ $0.214, d f=1, P=0.644)$ nor ticks infesting cats or dogs $\left(\chi^{2}=3,086, d f=1, P=0.079\right)$.

In total, $10.9 \%(n=15)$ I. hexagonus ticks were positive for at least one of the tested pathogens. Anaplasma phagocytophilum was the most common infection in 
Table 3 Ticks collected from dogs and cats infected with pathogens, the Wrocław Agglomeration (Poland), 2013-2014

\begin{tabular}{|c|c|c|c|c|c|c|c|c|c|c|c|}
\hline \multirow[t]{3}{*}{ Pathogens } & \multicolumn{11}{|c|}{ Number of infected ticks/number of investigated ticks (\%) } \\
\hline & \multicolumn{3}{|l|}{ 1. ricinus } & \multicolumn{4}{|c|}{ 1. hexagonus } & \multicolumn{3}{|l|}{ D. reticulatus } & \multirow[t]{2}{*}{ TOTAL } \\
\hline & $\bar{F}$ & M & $T$ & $\bar{F}$ & $\mathrm{~N}$ & $\mathrm{~L}$ & $T$ & $\bar{F}$ & M & $T$ & \\
\hline Rickettsia spp. & $59 / 115(51.3)$ & $5 / 12(41.7)$ & $64 / 127(50.4)$ & $2 / 32(6.3)$ & 1/98 (1.0) & $0 / 7(0.0)$ & $3 / 137(2.2)$ & 19/31 (61.3) & 9/15 (60.0) & $28 / 46(60.9)$ & $95 / 310(30.6)$ \\
\hline A. phagocytophilum & 25/112 (22.3) & $1 / 10(10.0)$ & $26 / 122(21.3)$ & $2 / 31(6.4)$ & 8/97 (8.2) & $1 / 7(14.3)$ & 11/135 (8.1) & - & - & - & $37 / 257(14.4)$ \\
\hline Cand. N. mikurensis & 10/113 (8.8) & 0/11 (0.0) & 10/124 (8.1) & $0 / 32(0.0)$ & 1/97 (1.0) & $0 / 7(0.0)$ & $1 / 136(0.7)$ & - & - & - & $11 / 260(4.2)$ \\
\hline Babesia spp. & 10/112 (8.9) & $1 / 10(10.0)$ & 11/122 (9.0) & $0 / 31(0.0)$ & $0 / 97(0.0)$ & $0 / 7(0.0)$ & 0/135 (0.0) & $0 / 31(0.0)$ & 0/15 (0.0) & $0 / 46(0.0)$ & 11/303 (3.6) \\
\hline
\end{tabular}

Abbreviations: $F$ females, $M$ males, $N$ nymphs, $L$ larvae, $T$ total 
these ticks $\left(\chi^{2}=20.661, d f=3, P<0.001\right)$, it was detected in $8.1 \%$ of ticks $(n=11)$; no statistically significant differences were observed between life stages $\left(\chi^{2}=0.473, d f=\right.$ 2, $P=0.789)$ or for ticks parasitizing cats or dogs $\left(\chi^{2}=\right.$ 1.373, $d f=1, P=0.241)$. Rickettsia spp. infection was found in $2.2 \%$ ticks $(n=3)$, there were no statistically significant differences between life stages, $\left(x^{2}=3.245, d f\right.$ $=2, P=0.197)$ or for ticks from different hosts $\left(\chi^{2}=\right.$ $0.166, d f=1, P=0.684$ ). Only one nymph specimen $(0.7 \%)$ was positive for Cand. N. mikurensis, with no statistical differences in infection levels between different life stages $\left(\chi^{2}=0.405, d f=2, P=0.817\right)$ or ticks collected from pets $\left(\chi^{2}=0.052, d f=1, P=0.82\right)$. None of the $I$. hexagonus ticks was found to be infected by Babesia spp.

Among $D$. reticulatus only Rickettsia spp. was detected; $60.9 \%$ of ticks were positive $(n=28)$. Statistically significant differences were not detected in infection levels between males and females $\left(\chi^{2}=0.007, d f=1, P=\right.$ $0.933)$ or ticks from cats or dogs $\left(\chi^{2}=0.175, d f=1, P=\right.$ 0.676). Babesia spp. DNA was not amplified in any of $D$. reticulatus sample.

Co-infections were detected only in I. ricinus ticks, mainly females. Only one male tick had a doubleinfection with Rickettsia spp. and A. phagocytophilum. The most common pathogen combination was Rickettsia spp. + A. phagocytophilum, followed by Rickettsia spp. + Cand. N. mikurensis, Rickettsia spp. + Babesia spp. and one of Cand. N. mikurensis + Babesia spp. (Table 4). Apart from these, two quadruple-infections and one triple-infection (Rickettsia spp., Cand. N. mikurensis, A. phagocytophilum.)

\section{Discussion}

From three ticks species identified as parasites of dogs and cats in the Wrocław Agglomeration, Ixodes ricinus was predominant, followed by $I$. hexagonus and $D$. reticulatus. Similar findings were obtained in Belgium [37], Switzerland [38], Germany [39] and Great Britain [40], as well as in Bosnia and Herzegovina [41].

Table 4 Co-infections in I. ricinus ticks collected from pets in the Wrocław Agglomeration (Poland), 2013-2014

\begin{tabular}{lc}
\hline Co-infections & $\begin{array}{c}\text { No. of ticks (collected } \\
\text { from cats/dogs) }\end{array}$ \\
\hline Rickettsia spp. + Babesia spp. & $3(1 / 2)$ \\
Rickettsia spp. + Cand. N. mikurensis & $4(1 / 3)$ \\
Rickettsia spp. + A. phagocytophilum & $11(3 / 8)$ \\
Cand. N. mikurensis + Babesia spp. & $2(2 / 0)$ \\
Rickettsia spp. + Cand. N. mikurensis + & $1(0 / 1)$ \\
A. phagocytophilum & \\
Rickettsia spp. + Cand. N. mikurensis + & $2(1 / 1)$ \\
A. phagocytophilum + Babesia spp. & \\
\hline
\end{tabular}

The prevalence of pathogens differed between the tick species. Ixodes ricinus individuals were the most often infected species. The lowest infection levels were observed in I. hexagonus ticks. From all tested pathogens (Rickettsia spp., Babesia spp., Candidatus Neoehrlichia mikurensis and Anaplasma phagocytophilum), rickettsial infections were the most common. The infection levels of A. phagocytophilum, Cand. N. mikurensis and Babesia spp. (B. microti, B. venatorum) were the highest in I. rici$n u s$ ticks and co-infections were detected only in this species. Interestingly, Babesia spp. DNA was only found in $I$. ricinus ticks, none of the $D$. reticulatus, the main vector for $B$. canis [42], was infected. The most often detected pathogen in $I$. hexagonus specimens was $A$. phagocytophilum. There were no statistically significant differences in infection levels between different tick life stages and between ticks collected from cats and dogs in any case. In Switzerland [43], researchers observed a difference in Rickettsia spp. infection levels between ticks from cats (40\%) and dogs (18\%), which was not found in this study.

Rickettsia spp. was dominant among $D$. reticulatus ticks (only $R$. raoultii) with prevalence over $60 \%$ and $I$. ricinus (only $R$. helvetica and R. monacensis) - over $50 \%$. Only $2 \%$ of Ixodes hexagonus ticks were infected. In Europe, prevalence of Rickettsia spp. in ticks infesting urban animals reached levels, e.g. 14-61 \% in I. ricinus, 1-44 \% of $I$. hexagonus, 14-39 \% of D. reticulatus [37, 44-46]. In Poland, the infection levels in the questing $I$. ricinus ticks were much lower than results obtained in this study; they differed from 6 to $23 \%[47,48]$ but prevalence in D. reticulatus was similar, 57 \% [49].

Anaplasma phagocytophilum infection levels of I. ricinus in this research were comparable to those reported in Belgium but much lower for I. hexagonus [37]. However, in The Netherlands and Germany, the prevalence was lower in I. ricinus ticks but similar to I. hexagonus $[44,50]$. In Poland, also in Lower Silesia, the infection of I. ricinus ticks (questing as well as collected from dogs) was lower than the data presented here [51-53].

Candidatus N. mikurensis was previously found in ticks in Poland [18], however, the detection in feeding $I$. hexagonus is the first one in the country. In Germany, the prevalence of this pathogen in I. ricinus and I. hexagonus from pets was $4 \%$ and $6 \%$, respectively [45], while in Denmark only $1 \%$ of I. ricinus was infected [46]. The prevalence in $I$. hexagonus ticks in the present study $(0.7 \%)$ is lower than in other countries; however, it is comparable to results obtained in a former study from Poland conducted on other tick species, I. ricinus (0.5\%) [18].

The prevalence of Babesia spp. (B. microti and $B$. venatorum) in I. ricinus was higher than in Belgium [54] and Germany [45], where the infection was also detected in $I$. hexagonus ticks. In Poland, also in Lower Silesia, only $1-3 \%$ of questing I. ricinus ticks were infected [52, 
$53,55]$. Similar to our results, all tested $D$. reticulatus in Germany were free of babesial parasites [45]. However, $11 \%$ of $D$. reticulatus ticks infesting dogs in central Poland were infected [51]; in Austria 2 of 6 specimens and in Hungary almost $30 \%$ of $D$. reticulatus (only female ticks) were positive for B. canis [56, 57].

As results of this study show, the risk of tick-borne diseases (TBD) is high in the Wrocław Agglomeration. However, due to the limitation of this study (no blood samples of dogs and cats were investigated for the pathogens), the tick-borne situation among pets in this area is not fully estimated. In Poland, canine tick-borne diseases pose an emerging veterinary problem. The most common TBD among dogs are $B$. canis and $A$. phagocytophilum reaching levels of 28 and $12 \%$, respectively $[58,59]$. Apart from the above, dogs were infected with Borrelia burgdorferi (s.l.), and Ehrlichia canis.

\section{Conclusion}

The high infection levels were detected for Rickettsia spp. ( $R$. raoultii, $R$. helvetica and $R$. monacensis), Anaplasma phagocytophilum, Candidatus Neoehrlichia mikurensis and Babesia spp. (B. microti and B. venatorum) in ticks infesting dogs and cats in the Wrocław Agglomeration, Poland. These findings, as well as the high tick infestation rates, demonstrate a serious level of encounter to tickborne diseases in urban dogs and cats in the Wrocław area, and provide evidence that dogs and cats themselves may substantially contribute to the circulation of the ticks and the pathogens in the urban area.

\section{Abbreviations \\ DEBONEL, dermacentor-borne necrosis erythema lymphadenopathy; SFG, spotted fever group; TBD, tick-borne disease; TIBOLA, tick-borne lymphadenopathy}

\section{Acknowledgement}

This study was partially financed by the European Union through the European Social Fund as well as by the University of Wrocław (grants numbers 1145/M/ IGM/13 and 2113/M/IGM/14). This paper has been sponsored by Bayer Animal Health in the framework of the 11th CVBD World Forum Symposium.

\section{Funding}

Not applicable.

\section{Availability of data and materials}

Not applicable.

\section{Authors' contributions}

NK organized the collection of samples, carried out the morphologic determination of ticks, and prepared the samples in the laboratory. MP, AO and NK designed, planned and organized the study. NK and AO tested the samples for pathogens, performed the sequence analysis. NK conducted data analysis. NK, AO, MP, DK and EL drafted the manuscript and wrote the final version. MP, DK and EL contributed to acquire funding. All authors read and approved the final manuscript.

\section{Competing interests}

The authors declare that they have no competing interests.
Ethics approval and consent to participate

Not applicable.

\section{Author details}

${ }^{1}$ Department of Microbial Ecology and Environmental Protection, Institute of Genetics and Microbiology, University of Wrocław, Przybyszewskiego 63/77, 51-148 Wrocław, Poland. ${ }^{2}$ Institute of Animal Hygiene and Veterinary Public Health, University of Leipzig, An den Tierkliniken 1, 04103 Leipzig, Germany.

Received: 31 March 2016 Accepted: 7 June 2016

Published online: 21 June 2016

\section{References}

1. Diniz PP, Schulz BS, Hartmann K, Breitschwerdt EB. "Candidatus Neoehrlichia mikurensis" infection in a dog from Germany. J Clin Microbiol. 2011;49: 2059-62.

2. Homer MJ, Aguilar-Delfin I, Telford 3rd SR, Krause PJ, Persing DH. Babesiosis. Clin Microbiol Rev. 2000;13(3):451-69.

3. Li H, Jiang JF, Liu W, Zheng YC, Huo QB, Tang K, Zuo SY, Liu K, Jiang BG, Yang H, Cao WC. Human infection with Candidatus Neoehrlichia mikurensis. China Emerg Infect Dis. 2012;18:1636-9

4. Woldehiwet Z. The natural history of Anaplasma phagocytophilum. Vet Parasitol. 2010;167(2-4):108-22.

5. Oteo JA, Portillo A. Tick-borne rickettsioses in Europe. Ticks Tick Borne Dis. 2012;3:271-8.

6. Solano-Gallego L, Kidd L, Trotta M, Di Marco M, Caldin M, Furlanello T, Breitschwerdt E. Febrile illness associated with Rickettsia conorii infection in dogs from Sicily. Emerg Infect Dis. 2006;12:1985-8.

7. Parola P, Paddock CD, Socolovschi C, Labruna MB, Mediannikov O, Kernif T, Abdad MY, Stenos J, Bitam I, Fournier PE, Raoult D. Update on tick-borne rickettsioses around the world: a geographic approach. Clin Microbiol Rev. 2013;26(4):657-702.

8. Ibarra V, Oteo JA, Portillo A, Santibanez S, Blanco JR, Metola L, et al. Rickettsia slovaca infection: DEBONEL/TIBOLA. Ann N Y Acad Sci. 2006;1078:206-14.

9. Podsiadły E, Chmielewski T, Karbowiak G, Kędra E, Tylewska-Wierzbanowska S. The occurrence of spotted fever rickettsioses and other tick-borne infections in forest workers in Poland. Vector Borne Zoonotic Dis. 2011;11:985-9.

10. Rymaszewska A, Adamska M. Molecular evidence of vector-borne pathogens coinfecting dogs from Poland. Acta Vet Hung. 2011:59:215-23.

11. Stańczak J. Detection of spotted fever group (SFG) rickettsiae in Dermacentor reticulatus (Acari: Ixodidae) in Poland. Int J Med Microbiol. 2006;296 Suppl 40:144-8

12. Grzeszczuk A, Stanczak J, Kubica-Biernat B, Racewicz M, Kruminis-Lozowska W, Prokopowicz D. Human anaplasmosis in north-eastern Poland: seroprevalence in humans and prevalence in Ixodes ricinus ticks. Ann Agric Environ Med. 2004;11:99-103.

13. Welc-Falęciak R, Kowalec M, Zajkowska J, Pancewicz SA, Siński E. Clinical and molecular features of one case of human infection with Anaplasma phagocytophilum from Podlaskie Province in eastern Poland. Ann Agric Environ Med. 2015:22(3):414-7.

14. Skotarczak B, Adamska M, Supron M. Blood DNA analysis for Ehrlichia (Anaplasma) phagocytophila and Babesia spp. in dogs from Northern Poland. Acta Vet Brno. 2004;73:347-51.

15. Gorna A, Adaszek L, Policht K, Skrzypczak M, Winiarczyk S. Detection of Anaplasma phagocytophilum in a cat. Vet Med. 2013;58:39-43.

16. Welinder-Olsson C, Kjellin E, Vaht K, Jacobsson S, Wenneras C. First case of human "Candidatus Neoehrlichia mikurensis" infection in a febrile patient with chronic lymphocytic leukemia. J Clin Microbiol. 2010;48(5):1956-9.

17. Welc-Falęciak R, Siński E, Kowalec M, Zajkowska J, Pancewicz SA. Asymptomatic "Candidatus Neoehrlichia mikurensis" infections in immunocompetent humans. J Clin Microbiol. 2014a:52(8):3072-4.

18. Welc-Falęciak R, Kowalec M, Karbowiak G, Bajer A, Behnke JM, Siński E. Rickettsiaceae and Anaplasmataceae infections in Ixodes ricinus ticks from urban and natural forested areas of Poland. Parasit Vectors. 2014b;7:121-10.

19. Wójcik-Fatla A, Bartosik K, Buczek A, Dutkiewicz J. Babesia microti in adult Dermacentor reticulatus ticks from eastern Poland. Vector Borne Zoonotic Dis. 2012;12(10):841-3.

20. Kiewra D, Stańczak J, Richter M. Ixodes ricinus ticks (Acari, Ixodidae) as a vector of Borrelia burgdorferi sensu lato and Borrelia miyamotoi in Lower Silesia. Poland-preliminary study. Ticks Tick Borne Dis. 2014;5(6):892-7. 
21. Rizzoli A, Silaghi C, Obiegala A, Rudolf I, Hubálek Z, Földvári G, et al. Ixodes ricinus and its transmitted pathogens in urban and peri-urban areas in Europe: New hazards and relevance for public health. Front Public Health. 2014:2:251.

22. Hamer SA, Tsao JI, Walker ED, Mansfield LS, Foster ES, Hickling GJ. Use of tick surveys and serosurveys to evaluate pet dogs as a sentinel species for emerging Lyme disease. Am J Vet Res. 2009;70(1):49-56.

23. Nowak-Chmura M, Siuda K. Ticks of Poland review of contemporary issues and latest research. Ann Parasitol. 2012;58:125-55.

24. Siuda K, Bliska M, Nowak M. Kleszcze (Acari: Ixodida: Ixodidae) atakujące psy domowe w okolicach Wadowic. Zoonozy: problem nadal aktualny. Conference Materials. Warszawa, 2002; 68. [in Polish].

25. Zygner W, Wedrychowicz $\mathrm{H}$. Occurrence of hard ticks in dogs from Warsaw area. Ann Agric Environ Med. 2006;13(2):355-9.

26. Michalski M, Sokół R. Ticks species (Ixodida) on dogs on Olsztyn city area. Ann Parasitol. 2013;59:180.

27. Martinod S, Brossard M, Moreau Y. Immunity of dogs against Babesia canis, its vector tick Dermacentor reticulatus, and Ixodes ricinus in endemic area. J Parasitol. 1985;71(3):269-73.

28. Mediannikov O, Matsumoto K, Samoylenko I, Drancourt M, Roux V, Rydkina E, Davoust B, Tarasevich I, Brouqui P, Fournier PE. Rickettsia raoultii sp. nov., a spotted fever group rickettsia associated with Dermacentor ticks in Europe and Russia. Int J Syst Evol Microbiol. 2008:58:1635-9.

29. Król N, Kiewra D, Szymanowski M, Lonc E. The role of domestic dogs and cats in the zoonotic cycles of ticks and pathogens. Preliminary studies in the Wrocław Agglomeration (SW Poland). Vet Parasitol. 2015;214:208-12.

30. Nowak-Chmura M. Fauna kleszczy (Ixodida) Europy Środkowej. Kraków: WNUP; 2013. [in Polish].

31. Wölfel R, Essbauer S, Dobler G. Diagnostics of tick-borne rickettsioses in Germany: A modern concept for a neglected disease. Int J Med Microbiol. 2008;298:368-74.

32. Courtney JW, Kostelnik LM, Zeidner NS, Massung RF. Multiplex real-time PCR for detection of Anaplasma phagocytophilum and Borrelia burgdorferi. J Clin Microbiol. 2004:42:3164-8.

33. Jahfari S, Fonville M, Hengeveld P, Reusken C, Scholte EJ, Takken W, Heyman P, Medlock J, Heylen D, Kleve J, Sprong H. Prevalence of Neoehrlichia mikurensis in ticks and rodents from north-west Europe. Parasit Vectors. 2012;5:74.

34. Silaghi C, Woll D, Mahling M, Pfister K, Pfeffer M. Candidatus Neoehrlichia mikurensis in rodents in an area with sympatric existence of the hard ticks Ixodes ricinus and Dermacentor reticulatus. Parasit Vectors. 2012;5:285.

35. Casati S, Sager H, Gern L, Piffaretti JC. Presence of potentially pathogenic Babesia sp. for human in Ixodes ricinus in Switzerland. Ann Agric Environ Med. 2006;13:65-70.

36. Roux V, Raoult D. Phylogenetic analysis of members of the genus Rickettsia using the gene encoding the outer-membrane protein rOmpB (ompB). Int J Syst Evol Microbiol. 2000;50:1449-55.

37. Claerebout E, Losson B, Cochez C, Casaert S, Dalemans AD, De Cat A, Madder M, Segerman C, Heyman P, Lempereur L. Ticks and associated pathogens collected from dogs and cats in Belgium. Parasit Vectors. 2013; doi:6: 183-10.1186/1756-3305-6-183.

38. Eichenberger RM, Deplazes P, Mathis A. Ticks on dogs and cats: A pet owner-based survey in a rural town in northeastern Switzerland. Ticks Tickborne Dis. 2015;6:267-71.

39. Beichel E, Petney TN, Hassler D, Brückner M, Maiwald M. Tick infestation patterns and prevalence of Borrelia burgdorferi in ticks collected at a veterinary clinic in Germany. Vet Parasitol. 1996;65:147-55.

40. Smith FD, Ballantyne R, Morgan ER, Wall R. Prevalence, distribution and risk associated with tick infestation of dogs in Great Britain. Med Vet Entomol. 2011;25:377-84

41. Krčmar SJ, Ferizbegović J, Lonić E, Kamberović J. Hard tick infestation of dogs in the Tuzla area (Bosnia and Herzegovina). Veterinarski Arhiv. 2014; 84(2):177-82.

42. Duh D, Slovák M, Saksida A, Strašek K, Petrovec M, Avšič-Županc T. Molecular detection of Babesia canis in Dermacentor reticulatus ticks collected in Slovakia. Biologia. 2006;61(2):231-3.

43. Boretti FS, Perreten A, Meli ML, Cattori V, Willi B, Wengi N, Hornok S, Honegger H, Hegglin D, Woelfel R, Reusch CE, Lutz H, Hofmann-Lehmann R. Molecular investigations of Rickettsia helvetica infections in dogs, foxes, humans and Ixodes ticks. Appl Environ Microbiol. 2009;75:3230-7.
44. Nijhof AM, Bodaan C, Postigo M, Nieuwenhuijs H, Opsteegh M, Franssen L, Jebbink F, Jongejan F. Ticks and associated pathogens collected from domestic animals in The Netherlands. Vector Borne Zoonotic Dis. 2007;7:111.

45. Schreiber C, Krücken J, Beck S, Maaz D, Pachnicke S, Krieger K, Gross M, Kohn B, von Samson-Himmelstjerna G. Pathogens in ticks collected from dogs in Berlin/Brandenburg, Germany. Parasit Vectors. 2014;7:535.

46. Stensvold CR, Al Marai D, O'Brien Andersen L, Krogfelt KA, Jensen JS, Søholt Larsen K, Nielsen HV. Babesia spp. and other pathogens in ticks recovered from domestic dogs in Denmark. Parasit Vectors. 2015;8:262.

47. Chmielewski T, Podsiadly E, Karbowiak G, Tylewska-Wierzbanowska S. Rickettsia spp. in ticks, Poland. Emerg Infect Dis. 2009;15(3):486-8.

48. Stańczak J, Racewicz M, Michalik J, Buczek A. Distribution of Rickettsia helvetica in Ixodes ricinus tick populations in Poland. Int J Med Microbiol. 2008:298:231-4.

49. Mierzejewska E, Welc-Falęciak R, Kowalec M, Alsarraf M, Bajer A. Comparison of prevalence of vector-borne pathogens in Dermacentor reticulatus from eastern and western Poland. The 16th International Symposium 'Parasitic and Allergic Arthropods - Medical and Sanitarny Significance'. Kazimierz Dolny. 2014:76

50. Krücken J, Schreiber C, Maaz D, Kohn M, Demeler J, Beck S, Schein E, Olias P, Richter D, Matuschka FR, Pachnicke S, Krieger K, Kohn B, von SamsonHimmelstjerna G. A novel high-resolution melt PCR assay discriminates Anaplasma phagocytophilum and "Candidatus Neoehrlichia mikurensis". J Clin Microbiol. 2013;51(6):1958-61.

51. Zygner W, Jaros S, Wędrychowicz H. Prevalence of Babesia canis, Borrelia afzelii, and Anaplasma phagocytophilum infection in hard ticks removed from dogs in Warsaw (central Poland). Vet Parasitol. 2008;153:139-42.

52. Sytykiewicz H, Karbowiak G, Hapunik J, Szpechciński A, Supergan-Marwicz M, Goławska S, Sprawka I, Czerniewicz P. Molecular evidence of Anaplasma phagocytophilum and Babesia microti co-infections in Ixodes ricinus ticks in central-eastern region of Poland. Ann Agric Environ Med. 2012;19:45-9.

53. Kiewra D, Zaleśny G, Czułowska A. The risk of infection with Anaplasma phagocytophilum and Babesia microti in Lower Silesia, SW Poland. In: Buczek A, Błaszak C, editors. Stawonogi: Zagrożenie zdrowia człowieka i zwierząt. Lublin: Koliber; 2014. 103-110.

54. Lempereur L, Decat A, Caron Y, Madder M, Claerebout E, Saegerman C, Losson B. First molecular evidence of potentially zoonotic Babesia microti and Babesia sp. EU1 in Ixodes ricinus ticks in Belgium. Vector Borne Zoonotic Dis. 2011;11:125-30

55. Cieniuch S, Stańczak J, Ruczaj A. The first detection of Babesia EU1 and Babesia canis canis in Ixodes ricinus ticks (Acari, Ixodidae) collected in urban and rural areas in northern Poland. Pol J Microbiol. 2009;58(3):231-6.

56. Leschnik MW, Khanakah G, Duscher G, Wille-Piazzai W, Hörweg C, Joachim A, Stanek G. Species, developmental stage and infection with microbial pathogens of engorged ticks removed from dogs and questing ticks. Med Vet Entomol. 2012;26(4):440-6.

57. Földvári G, Márialigeti M, Solymosi N, Lukács Z, Majoros G, Kósa JP, et al. Hard ticks infesting dogs in Hungary and their infection with Babesia and Borrelia species. Parasitol Res. 2007;101:25-34.

58. Welc-Falęciak R, Rodo A, Siński E, Bajer A. Babesia canis and other tick-borne infections in dogs in Central Poland. Vet Parasitol. 2009;166:191-8.

59. Krämer F, Schaper R, Schunack B, Połozowski A, Piekarska J, Szwedko A, Jodies R, Kowalska D, Schüpbach D, Pantchev N. Serological detection of Anaplasma phagocytophilum, Borrelia burgdorferi sensu lato and Ehrlichia canis antibodies and Dirofilaria immitis antigen in a countrywide survey in dogs in Poland. Parasitol Res. 2014;113(9):3229-39. 